\title{
Persepsi Masyarakat Terhadap Keefektifan Penggunaan Kwhmeter Prabayar Di Wilayah Betngandang Sanur Bali
}

\author{
Putu Agus Mahadi Putra ${ }^{1}$, D. A. S. Santiari ${ }^{2}$, Tjokorda Bagus Putra M.
}

\begin{abstract}
In an effort to improve the quality of service and overcome problems such as, electricity customers are not disciplined in paying utility bills each month, metering errors made by PLN employees, and electricity theft. Then PT. PLN issued and implemented a pre-paid electricity system. To find out the public perception of the effectiveness of the prepaid product kWhmeter for the community (middle aged customers (45-59th) and elderly ( $\geq 60$ th), this study investigates the use of products in the Br.Betngandang area of Sanur, Bali. The design of this paper is descriptive by conducting surveys to people's homes. Based on population of head of household in region Br. Betngandang obtained the number of samples of 74. To know the public perception of the effectiveness of the use of $\mathrm{kWhmeter}$ prepaid then the community is given a questionnaire with 11 statements and 4 questions to be filled. The results in this paper are in the range of $60 \%-80 \%$ indicating that the use of prepaid $\mathrm{kWhmeter}$ products provides a relatively strong effectiveness and this makes a good public perception of prepaid kWhmeter products.
\end{abstract}

Intisari- Dalam upaya meningkatkan kualitas pelayanan dan mengatasi masalah seperti, pelanggan listrik tidak disiplin dalam membayar tagihan rekening listrik tiap bulan, kesalahan catat meter yang dilakukan oleh pegawai PLN, pencurian listrik maka PT. PLN megeluarkan dan menerapkan sistem listrik prabayar. Untuk mengetahui persepsi masyarakat terhadap keefektifan dari produk $\mathrm{kWhmeter}$ prabayar bagi masyarakat (pelanggan umur pertengahan $(45-59$ th) dan lansia $(\geq 60$ th), pada paper ini dilakukan penelitian terhadap penggunaan produk di wilayah Br.Betngandang Sanur, Bali. Rancangan pada paper ini ialah berbentuk deskriptif dengan melakukan survey ke rumah-rumah warga. Berdasarkan jumlah populasi kepala keluarga di wilayah Br. Betngandang diperoleh jumlah sampel sebesar 74. Untuk mengetahui persepsi masyarakat terhadap kefektifan penggunaan kWhmeter prabayar maka masyarakat diberikan kuisioner dengan 11 pernyataan dan 4 pertanyaan yang harus diisi. Hasil pada paper ini berada pada rentang $60 \%-80 \%$ menunjukkan bahwa penggunaan dari produk kWhmeter prabayar memberikan efektifitas yang tergolong kuat dan hal ini membuat persepsi masyarakat menjadi baik terhadap produk kWhmeter prabayar.

Kata Kunci - - kWhmeter prabayar, Token listrik, Energi listrik, Efektif

\section{PENDAHULUAN}

Energi listrik merupakan energi yang vital bagi manusia, karena hampir semua kegiatan manusia mulai dari kegiatan di rumah tangga, rumah sakit, perkantoran, sekolah, pabrik dan lain-lain sangat membutuhkan energi listrik. Data PT. PLN (Persero) untuk penggunaan listrik sampai tahun 2015

${ }^{1,2,3}$ Dosen Teknik Elektromedik, Institut Ilmu Kesehatan Medika Persada Bali, Denpasar, Bali, INDONESIA;

e-mail: 'Imahadi.putra@gmail.com,22dwayusanti@gmail.com, ${ }^{3}$ tjokbgs@gmail.com.

Putu Agus Mahadi Putra : Analisa Biaya Penggunaan Bersama... menunjukkan bahwa dari total 60,9 juta pelanggan PLN di seluruh Indonesia, 56,3 juta $(92,4 \%)$ di antaranya merupakan golongan rumah tangga. Diikuti golongan bisnis sebesar 2,8 juta $(4,6 \%)$, golongan industri sebesar 61 ribu $(0,1 \%)$ dan golongan publik sebesar 1,7 juta $(2,8 \%)$ (http://pln.co.id). Saat ini PT.PLN merupakan satu-satunya perusahaan dibidang jasa yang bergerakpada aspek kelistrikan di Indonesia. Masih tingginya penyusutan energi, tenaga listrik yang masih naik turun (tidak stabil), pembaca meter yang kurang akurat dilakukan oleh petugas pencatatan kWhmeter, kurangnya kualitas pelayanan, dan keluhan-keluhan lainnya merupakan beberapa masalah yang senantiasa menjadi sorotan dan dapat menghambat kinerja PT PLN.

PT. PLN selaku pemasok energi listrik, sampai saat ini hanya memasang KWH meter sebagai alat pengukur pemakaian energi dan MCB, sebagai pembatas daya tersambung [9]. Alat ukur ini dipergunakan untuk mengetahui jumlah energi listrik yang dikonsumsi pelanggan.Pada umumnya produk $\mathrm{kWhmeter}$ yang digunakan oleh PLN adalah kWhmeter analog atau konvensional sehingga perlu petugas pembaca meter untuk melakukan pencatatan data dan transfer kedatabase PLN. Pelanggan biasanya menggunakan listrik terlebih dahulu dan membayar tagihannya pada bulan berikutnya. Sistem perhitungan yang masih manual ini sering menimbulkan masalah seperti seringnya pelanggan listrik tidak disiplin dalam membayar tagihan rekening listrik tiap bulan, kesalahan catat meter yang dilakukan oleh pegawai PLN, tindakan pencurian energi listrik, dll, sehingga membuat PLN megeluarkan dan menerapkan sistem listrik prabayar. Dalam upaya untuk mengatasi masalah yang ada dan meningkatkan kualitas pelayanan mereka terhadap pelanggan, maka PLN akhirnya melakukan usaha inovasi mengeluarkan produk $\mathrm{kWh}$ meter prabayar yang didukung dengan kecanggihan teknologi. Produk kWhmeter ini sering juga disebut listrik prabayar,yaitu sistem listrik yang menggunakan kWhmeter digital, dimana pelanggan harus membeli Token listrik. Akhirnya besar Token listrik yang telah dibeli oleh pelanggan, akan didapatkan 20 digit kode unik untuk dimasukkan ke dalam meter prabayar (MPB).

Menurut PT. PLN penggunaan produk $\mathrm{kWhmeter} \mathrm{prabayar}$ atau sering pula disebut dengan meteran pulsa, memiliki banyak keuntungan antara lain : pemakaian listrik lebih terkendali, tanpa ada sanksi pemutusan, tanpa dikenakan denda keterlambatan, tanpa uang jaminan pelanggan, tanpa ada pencatatan meter, privasi tidak terganggu, tidak dikenakan biaya beban bulanan, kemudahan pembelian Token, pembelian disesuaikan kemampuan, dan tidak ada batas masa aktif (aktif selama kWh masih tersisa). Disamping banyaknya keuntungan yang ditawarkan oleh pihak PLN, ternyata ada beberapa permasalahan yang dikeluhkan oleh masyarakat.

Penelitiaan sebelumnya sudah pernah dilakukan di wilayah Kenten, Palembang oleh Purwati [1]. Pada penelitian tersebut

$$
\text { p-ISSN:1693 - 2951; e-ISSN: 2503-2372 }
$$


purwati menyatakan bahwa masih kurangnya sosialisasi dari pihak PT. PLN kepada masyarakat walaupun tingkat keefektifan yang didapat sebesar $69,55 \%$, kemudian pada paper ini terdapat beberapa permasalahan baru yakni, susahnya memasukkan pulsa listrik ke kWhmeter prabayar, sulitnya memperoleh Token listrik disaat mendesak (misal, malam hari) karena sedikitnya loket untuk membeli Token, berisiknya bunyi yang dikeluarkan oleh kWhmeter pada saat pulsa listrik mau habis adalah beberapa permasalahan yang umum dikeluhkan oleh pelanggan PT. PLN. Untuk beberapa pelanggan, proses memasukkan pulsa listrik ke kWhmeter prabayar dirasakan cukup sulit. Ini dikarenakan mereka harus memasukkan beberapa angka pada layar kWhmeter. Masyarakat dalam paper ini merupakan para pelanggan umur pertengahan (45-59th) dan lansia ( $\geqslant 60$ th), dengan penurunan daya penglihatan tentu merasakan kesulitan saat harus melakukan proses memasukkan pulsa listrik. Mereka harus menggunakan alat bantu penglihatan (kacamata) untuk dapat melakukan proses pemasukkan pulsa ke kWhmeter prabayar. Untuk mengetahui keefektifan dari produk kWhmeter prabayar yang sudah diluncurkan oleh PT PLN bagi pelanggan umur pertengahan (45-59th) dan lansia $(\geqslant 60$ th), maka pada paper ini kami akan meneliti bagaimana persepsi masyarakat terhadap keefektifan dari penggunaan produk tersebut setelah beberapa tahun dikeluarkan di wilayah Br.Betngandang Sanur, Bali.

\section{TINJAUAN PUSTAKA}

\section{A. kWhmeter Prabayar PLN}

kWhmeter prabayar milik PLN dirancang dengan menggunakan teknologi kWhmeter elektrik yang baru dan sangat berbeda dengan kWhmeter analog walaupun fungsinya sama. Ada 28 merk kWhmeter listrik prabayar yang selama ini sudah digunakan oleh PLN yakni : Hexing, Itron, Glomet, Smartmeter, Melcoinda, Actaris, Inhemeter, Conlog, Landis, Cannet, Prima, Holleymet, Genus, Akari, Apator, Holleyindo, Wasion, Catic, Kaifa, Joymeter, ATC, Star, Sanxing, Metbelosa, Fuji, Meisys, Holley, dan Sunrise. Pada dasarnya cara kerja kWhmeter prabayar itu sama dengan $\mathrm{kWhmeter}$ analog. Alat ini bekerja menggunakan metode induksi medan untuk menggerakkan piringan yang terbuat dari aluminium. Piringan tersebut akan berputar dan menggerakkan counter digit sebagai tampilan jumlah kWhnya[8]. Prinsipnya kerja $\mathrm{kWh}$ meter prabayar pelanggan membeli token atau pulsa $\mathrm{kWh}$ terlebih dahulu, baru pelanggan bisa menikmati listrik PLN.

Hal yang wajib diketahui oleh pelanggan listrik pengguna $\mathrm{kWh}$ prabayar adalah cara memasukkan token atau pulsa listrik. Pelanggan membeli token atau pulsa listrik ke tempat pembelian pulsa prabayar (konter, PPOB, KUD, dan bank) dengan membawa kartu prabayar yang diberikan pihak PLN atau tinggal bawa no id pelanggan atau nomor meter yang ada pada kartu atau yang tertera di kWh meter prabayar jika kartu hilang. Setelah pelanggan mendapatkan no token sebanyak 20 digit, masukkan dengan cara menekan tombol pada kwh prabayar sesuai dengan no token. Setelah semua nomor masuk tekan tombol enter atau tombol panah melengkung (kanan bawah), maka jumlah kWh meter listrik prabayar Anda sudah bertambah. Jika ada kesalah tekan nomor, hapus saja dengan menekan tombol hapus (tombol panah kiri bawah).

\section{B. Kepuasan Pelanggan}

Kepuasan adalah perasaan seseorang mengenai kesenangan atau hasil yang mengecewakan dari membandingkan penampilan produk yang telah disediakan (hasil) dalam yang berhubungan dengan harapan si pelanggan.[7]. Atau secara singkat adalah memenuhi kebutuhan pelanggan. Pelanggan yang puas akan melakukan bisnis lebih banyak dan lebih sering dengan suatu perusahaan, sehingga keuntungan perusahaan semakin besar. Setyawan dan Susila menyatakan bahwa kepuasan pelanggan merupakan evaluasi spesifik terhadap keseluruhan pelayanan yang diberikan pemberi jasa, sehingga kepuasan pelanggan hanya dapat dinilai berdasarkan pengalaman yang pernah dialami saat proses pemberian pelayanan. Kepuasan pelanggan ditentukan oleh pelayanan yang diberikan baik secara tangible maupun intangible, dalam hal ini penilaian dilakukan oleh pelanggan mengenai kategori jasa yang diberikan [2].

\section{Definisi Efektifitas}

Efektifitas pada dasarnya menunjukkan pada taraf tercapainya hasil, sering atau senantiasa dikaitkan dengan pengertian efisien, meskipun sebenarnya ada perbedaan diantara keduanya. Efektifitas menekankan pada hasil yang dicapai [3]. Kemudian menurut Martoyo menyatakan bahwa efektifitas dapat pula diartikan sebagai suatu kondisi atau keadaan, dimana dalam memilih tujuan yang hendak dicapai dan sarana yang digunakan, serta kemampuan yang dimiliki adalah tepat, sehingga tujuan yang diinginkan dapat dicapai dengan hasil yang memuaskan.

\section{Populasi Penelitian}

Populasi merupakan wilayah generalisasi yang terdiri atas objek/subjek yang mempunyai kualitas dan karakteristik tertentu yang ditetapkan oleh peneliti untuk dipelajari dan kemudian ditarik kesimpulannya [4]. Berdasarkan data dari Kepala Lingkungan Br. Betngandang Sanur tahun 2016, diperoleh bahwa jumlah populasi di wilayah ini adalah sebanyak 282.

\section{E. Sampel Penelitan}

Sampel adalah sebagian dari jumlah dan karakteristik yang dimiliki dan diwakili oleh populasi yang menjadi perhatian penelitian. Pertanyaan yang seringkali diajukan dalam metode pengambilan sampel adalah berapa jumlah sampel yang dibutuhkan dalam penelitian. Sampel yang terlalu kecil dapat menyebabkan penelitian tidak dapat menggambarkan kondisi populasi yang sesungguhnya. Sebaliknya, sampel yang terlalu besar dapat mengakibatkan pemborosan biaya penelitian. Salah satu metode yang digunakan untuk menentukan jumlah sampel adalah menggunakan rumus Slovin [5], yaitu:

$$
n=\frac{N}{1+N(e)^{2}}
$$


$\mathrm{n}=$ Jumlah sampel

$\mathrm{N}=$ Jumlah populasi

$\mathrm{e}=$ Taraf kesalahan (Pada penelitian ini digunakan 10\%)

Batas toleransi kesalahan menggunakan jumlah persentase. Semakin kecil toleransi kesalahan, semakin akurat sampel menggambarkan populasi. Dalam paper ini jumlah populasi kepala keluarga di wilayah Br. Betngandang Sanur adalah 287. Kemudian dengan menggunakan persamaan (1) didapatkan jumlah sampel sebesar 74 dengan tingkat kesalahan $10 \%$.

\section{F. Indeks Skor (IS)}

Indeks Skor (IS) digunakan untuk mengetahui besar persentase jawaban yang didapat dari para responden. Menurut Yusi, rumus perhitungannya yaitu [6]:

$I S=\frac{\sum \text { Skor Penelitian }}{\sum \text { SkorIdeal }} \times 100 \%$

Keterangan Kriteria Interpretasi Skor:

$0 \%-20 \%=$ Sangat tidak efektif.

$21 \%-40 \%=$ Tidak efektif.

$41 \%-60 \%=$ Cukup efektif.

$61 \%-80 \%=$ Efektif.

$81 \%-100 \%=$ Sangat efektif.

Jumlah Skor Ideal $=($ skala nilai tertinggi) $\mathrm{x}$ (jumlah responden)

\section{Methodologi}

Pada Paper ini menggunakan konsep survey door to door dari satu rumah warga ke rumah warga lainnya dengan membawa kuisioner yang telah disiapkan (dapat dilihat di lampiran). Adapun variabel penilaian pada paper ini digunakan skala likert yakni 1-5. Selengkapnya dapat dilihat pada tabel I.

Tabel I.

HUBUNGAN ANTAR VARIABEL

\begin{tabular}{|l|c|c|c|c|c|}
\hline & $\begin{array}{c}\text { SS } \\
\text { PERNYATAAN }\end{array}$ & $\begin{array}{c}\text { S } \\
\text { Sangat } \\
\text { Setuju) }\end{array}$ & $\begin{array}{c}\text { CS } \\
\text { u) }\end{array}$ & $\begin{array}{c}\text { TS } \\
\text { (Cukup } \\
\text { Setuju) }\end{array}$ & $\begin{array}{c}\text { STS } \\
\text { (Tidak } \\
\text { Setuju) }\end{array}$ \\
$\begin{array}{c}\text { Sangat } \\
\text { Tidak } \\
\text { Setuju) }\end{array}$ \\
\hline SCORING & 5 & 4 & 3 & 2 & 1 \\
\hline
\end{tabular}

Kemudian untuk mencari persentase dari indeks skor, mula-mula harus dicari berapa jumlah skor ideal yakni menggunakan rumus : Jumlah Skor Ideal $=$ (skala nilai tertinggi) x (jumlah responden (sample)). Setelah didapatkan skor ideal tersebut, maka itu merupakan skor maksimum yang digunakan untuk dijadikan pembagi total skor yang didapatkan dari masing-masing pernyataan. Sehingga pada akhirnya diketahui berapa \% indeks skor dari masing-masing pernyataan, Nilai skala tertinggi adalah 5, kemudian nilai jumlah responden adalah 74.Hasil perhitungan menggunakan persamaan (2) didapatkan jumlah skor ideal sebesar 370. Jadi misalkan total jumlah skor dari satu pernyataan anggap saja pernyataan X1, totalnya 287 maka persentasenya adalah 77\% dimana angka ini hasilnya efektif.

Putu Agus Mahadi Putra : Analisa Biaya Penggunaan Bersama....

\section{IV.SIMULASI DAN PEMBAHASAN}

A. Peta dan Kondisi Wilayah Banjar Betngandang Desa Sanur Kauh

Sanur merupakan salah satu kawasan pariwisata tertua di Bali yang paling pertama memiliki resort. Destinasi pariwisata ini mulai dikunjungi sejak tahun 1930-an. Desa Sanur memiliki tiga wilayah bagian, yakni: Kelurahan Sanur, Sanur Kauh, dan Sanur Kaja. Banjar Betngandang termasuk kedalam wilayah Desa Sanur Kauh. Banjar Betngandang terletak dekat dengan pantai kurang lebih $700 \mathrm{~m}$ dari bibir pantai Hyatt sanur atau tepatnya di jalan Bypass Ngurah Rai. Banjar Betngandang memiliki Kelihan Adat dan Kelihan Dusun. Kelihan Adat bertugas untuk mengatur segala kegiatan yang berkaitan dengan kegiatan adat di Banjar maupun di Desa Adat. Kemudian tugas dari Kelihan Dusun ialah mengurus prihal mengenai kependudukan yang berkaitan dengan kegiatan catatan sipil seperti, pembuatan KTP, pernikahan, pengurusan kartu keluarga,dll. Luas wilayah dari wilayah Betngandang ialah 28,00 ha dengan jumlah kepala keluarga sebanyak 287 orang.

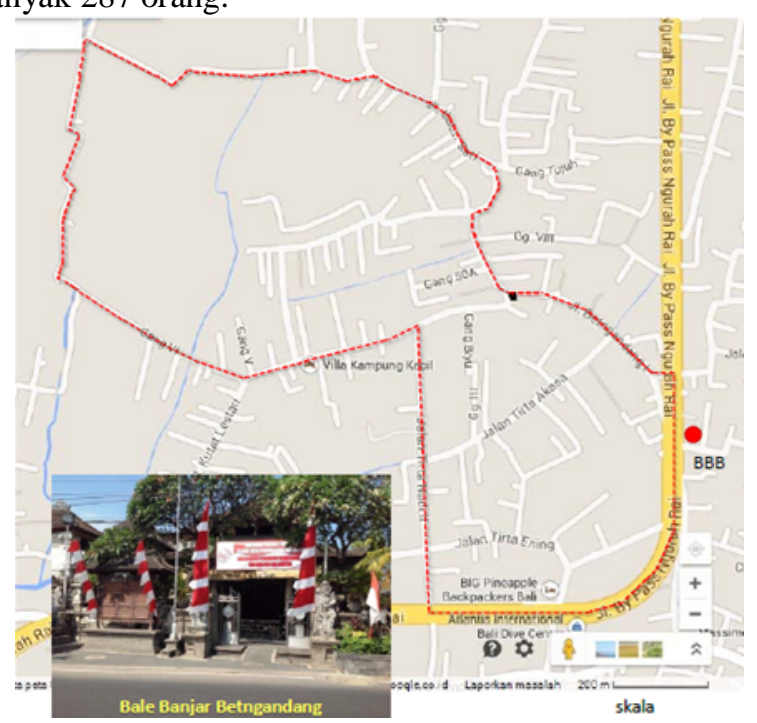

Gambar 1. Peta wilayah Betngandang Desa Sanur Kauh

B. Efektifitas Penggunaan kWhmeter Prabayar

Berdasarkan kuisioner yang telah dicari oleh peneliti yang dibantu oleh petugas survey lapangan, kuisioner yang sudah diisi oleh para responden (data responden dapat dilihat pada lampiran) direkap pada tabel II.

Tabel II.

REKAP PERNYATAAN DAN PERTANYAAN DARI RESPONDEN

\begin{tabular}{|l|l|c|c|c|c|c|}
\hline No & \multicolumn{1}{|c|}{ Pernyataan } & SS & S & CS & TS & STS \\
\hline 1 & $\begin{array}{l}\text { Pemakaian kWhmeter prabayar } \\
\text { lebih murah }\end{array}$ & 0 & 22 & 25 & 27 & 0 \\
\hline 2 & $\begin{array}{l}\text { Saat memasukkan nomor token } \\
\text { pada kWhmeter prabayar sangat } \\
\text { mudah dan terlihat dengan jelas } \\
\text { pada monitor kWhmeter }\end{array}$ & 1 & 66 & 5 & 2 & 0 \\
\hline
\end{tabular}

p-ISSN:1693 - 2951; e-ISSN: 2503-2372 


\begin{tabular}{|l|l|l|l|l|l|l|}
\hline 3 & $\begin{array}{l}\text { kWhmeter prabayar memudahkan } \\
\text { pelanggan untuk memantau } \\
\text { pemakaian listrik melalui monitor } \\
\text { kWhmeter dan dapat dilihat } \\
\text { dengan jelas }\end{array}$ & 3 & 66 & 4 & 1 & 0 \\
\hline 4 & $\begin{array}{l}\text { Loket untuk pembelian token } \\
\text { listrik sangat mudah dicari dan } \\
\text { tersedia dekat dengan rumah anda }\end{array}$ & 8 & 61 & 5 & 0 & 0 \\
\hline 5 & $\begin{array}{l}\text { Pemakaian kWhmeter prabayar } \\
\text { lebih aman }\end{array}$ & 4 & 36 & 33 & 1 & 0 \\
\hline 6 & $\begin{array}{l}\text { kWhmeter prabayar merupakan } \\
\text { wujud peningkatan kualitas } \\
\text { pelayanan PT PLN (Persero) }\end{array}$ & 5 & 28 & 39 & 2 & 0 \\
\hline 7 & $\begin{array}{l}\text { Pelanggan dapat mendisiplikan } \\
\text { diri untuk menggunakan energi } \\
\text { listrik }\end{array}$ & 4 & 46 & 23 & 1 & 0 \\
\hline 8 & $\begin{array}{l}\text { kWhmeter prabayar membantu } \\
\text { pelanggan untuk melakukan } \\
\text { hemat energi }\end{array}$ & 3 & 29 & 23 & 19 & 0 \\
\hline 9 & $\begin{array}{l}\text { Pelanggan terhindar dari biaya } \\
\text { abodemen dan denda } \\
\text { keterlambatan pembayaran }\end{array}$ & 6 & 43 & 24 & 1 & 0 \\
\hline 10 & $\begin{array}{l}\text { Pelanggan merasa nyaman karena } \\
\text { tidak lagi didatangi petugas } \\
\text { pencatat meter }\end{array}$ & 5 & 52 & 17 & 0 & 0 \\
\hline 11 & $\begin{array}{l}\text { kWhmeter prabayar } \\
\text { mengeluarkan suara bising saat } \\
\text { pulsa sudah hampir habis dan } \\
\text { tidak membuat pelanggan } \\
\text { terganggu }\end{array}$ & 5 & 43 & 14 & 11 & 1 \\
\hline Rekap Pertanyan : & & & & \\
\hline
\end{tabular}

Rekap Pertanyaan :

1. Menurut Anda, apakah produk kWhmeter prabayar yang dikeluarkan PT PLN (Persero) sudah efektif memenuhi harapan pelanggan?

Jawaban:

Ya : $69(93,24 \%)$, Tidak : $5(6,76 \%)$, dan Tidak menjawab : $0(0 \%)$

2. Apakah produk kWhmeter prabayar membantu Anda untuk terhindar daripemborosan energi?

Jawaban:

Ya : $47(63,51 \%)$, Tidak : $27(36,49 \%)$, dan Tidak menjawab : $0(0 \%)$

3. Apakah produk kWhmeter prabayar memberikan keuntungan bagi Anda? Jelaskan jika ada

Jawaban:

Ada : $32(43,24 \%)$, Tidak ada : $42(56,76 \%)$, dan Tidak menjawab : $0(0 \%)$

Berdasarkan jawaban responden, keuntungan yang didapat dalam pemakaian $\mathrm{kWhmeter} \mathrm{prabayar} \mathrm{ialah} \mathrm{:}$

a. Mudah dalam pemantauan pemakaian energi listrik

b. Mudah dalam pembelian Token

c. Tidak perlu mengantri dalam pembayaran

d. Mudah dalam pengaturan pemakaian energi listrik

4. Apakah produk kWhmeter prabayar memberikan kendala bagi Anda? Jelaskan jika ada

Jawaban:
Ada : $14(18,91 \%)$, Tidak ada : 60 (81,09\%), dan Tidak menjawab : $0(0 \%)$

Berdasarkan jawaban responden, kendala yang didapat dalam pemakaian $\mathrm{kWhmeter}$ prabayar ialah :

a. Jumlah $\mathrm{kWh}$ yg didapat tidak sesuai dengan yang harga yang dibayarkan

b. Malam hari saat pulsa habis susah untuk membeli Token

c. kWhmeter mengeluarkan suara bising saat pulsa hampir habis

Berikut ini adalah pembahasan dari setiap pernyataan yang berkaitan dengan efektifitas dari penggunaan kWhmeter Prabayar yakni, Pemakaian kWhmeter Prabayar Lebih Murah dapat dilihat pada tabel III.

Tabel III.

PEMAKAIAN KWHMETER PRABAYAR LEBIH MURAH Pernyataan 1

\begin{tabular}{|l|c|c|c|c|c|c|}
\hline & SS & S & CS & TS & STS & Total \\
\hline Skor & 5 & 4 & 3 & 2 & 1 & \\
\hline Jumlah Jawaban & 0 & 22 & 25 & 27 & 0 & 74 \\
\hline Total skor & 0 & 88 & 75 & 54 & 0 & 217 \\
\hline Indeks Skor & \multicolumn{7}{|l|}{} \\
\hline
\end{tabular}

Berdasarkan perhitungan di atas, dapat dilihat bahwa pada pernyataan 1, nilai indeks skor jawaban responden sebesar $58,65 \%$. Persentase ini menunjukkan nilai "cukup efektif " untuk pernyataan bahwa kWhmeter prabayar lebih murah. Hal ini karena memang tidak ada perbedaan harga yang signifikan antara harga per-kWh pada konsumen prabayar dengan konsumen pasca bayar.

Dengan cara yang sama, rekap hasil perhitungan dari setiap pernyataan yang berkaitan dengan efektifitas penggunaan $\mathrm{kWhmeter}$ prabayar dapat dilihat pada tabel IV.

Tabel IV.

REKAP HASIL PERSENTASE SETIAP PERNYATAAN DAN PERTANYAAN

\begin{tabular}{|l|l|c|l|}
\hline No & Pernyataan tertutup & Persentase Hasil \\
\hline 1 & $\begin{array}{l}\text { Pemakaian kWhmeter prabayar lebih } \\
\text { murah }\end{array}$ & $58,65 \%$ & $\begin{array}{l}\text { Cukup } \\
\text { Efektif }\end{array}$ \\
\hline 2 & Kemudahan Memasukkan Nomor & $77,84 \%$ & Efektif \\
\hline 3 & Kemudahan Memantau Pemakaian & $79,19 \%$ & Efektif \\
\hline 4 & Kemudahan Memperoleh Token Listrik & $80,81 \%$ & Efektif \\
\hline 5 & $\begin{array}{l}\text { Pemakaian kWhmeter Prabayar Lebih } \\
\text { Aman }\end{array}$ & $71,62 \%$ & Efektif \\
\hline 6 & $\begin{array}{l}\text { Perwujudan Peningkatan Kualitas } \\
\text { Pelayanan PT. PLN }\end{array}$ & $69,73 \%$ & Efektif \\
\hline 7 & $\begin{array}{l}\text { Kedisiplinan Menggunakan Energi } \\
\text { Listrik }\end{array}$ & $74,32 \%$ & Efektif \\
\hline 8 & $\begin{array}{l}\text { Alat kWhmeter Prabayar Membantu } \\
\text { Menghemat Energi }\end{array}$ & $64,32 \%$ & Efektif \\
\hline 9 & $\begin{array}{l}\text { Konsumen Terhindar dari Biaya } \\
\text { Abodemen dan Denda Keterlambatan }\end{array}$ & $74,59 \%$ & Efektif \\
\hline 10 & Tingkat Kenyamanan & $76,76 \%$ & Efektif \\
\hline 11 & Tingkat Kebisingan kWhmeter & $70,81 \%$ & Efektif \\
\hline
\end{tabular}




\begin{tabular}{|l|l|c|l|}
\hline & Rata-rata pernyataan & $\mathbf{7 2 , 6 0 \%}$ & Efektif \\
\hline & Pertanyaan terbuka & & \\
\hline 1 & $\begin{array}{l}\text { Menurut Anda, apakah produk kwh- } \\
\text { prabayar yang dikeluarkan PT PLN } \\
\text { (Persero) sudah efektif memenuhi } \\
\text { harapan pelanggan? }\end{array}$ & $93,24 \%$ & Efektif \\
\hline 2 & $\begin{array}{l}\text { Apakah produk kwh-prabayar } \\
\text { membantu Anda untuk terhindar dari } \\
\text { pemborosan energi? }\end{array}$ & $63,51 \%$ & Efektif \\
\hline 3 & $\begin{array}{l}\text { Apakah produk kWhmeter prabayar } \\
\text { memberikan keuntungan bagi Anda? } \\
\text { Jelaskan jika ada }\end{array}$ & $43,24 \%$ & $\begin{array}{l}\text { Cukup } \\
\text { Efektif }\end{array}$ \\
\hline 4 & $\begin{array}{l}\text { Apakah produk kWhmeter prabayar } \\
\text { memberikan kendala bagi Anda? } \\
\text { Jelaskan jika ada }\end{array}$ & $81,09 \%$ & Efektif \\
\hline Rata-rata pertanyaan & $\mathbf{7 0 , 2 7 \%}$ & Efektif \\
\hline & $\begin{array}{l}\text { Rata-rata Pernyataan \& Pertanyaan } \\
\text { Berdasank }\end{array}$ & $\mathbf{7 1 , 4 3 \%}$ & Efektif \\
\hline
\end{tabular}

Berdasarkan tabel IV dapat dilihat rata-rata dari pernyataan adalah $72,60 \%$ dan rata-rata persentase dari pertanyaan sebesar $70,27 \%$. Rata-rata hasil dari keduanya adalah $(72,60 \%+70,27 \%): 2=71,43 \%$. Hal ini menunjukkan bahwa efektifitas tergolong " kuat (60\%-80\%)" dilihat dari rata-rata persentase Indeks Skor (IS). Dari persentase hasil yang didapat bahwa penggunaan $\mathrm{kWhmeter}$ prabayar tergolong sudah efektif karena berdasarkan hasil survey yang dilakukan membuat persepsi masyarakat menjadi baik terhadap penggunaan dari produk kWhmeter prabayar oleh PT.PLN (Persero) di wilayah Betngandang Sanur.

\section{SIMPULAN}

Hasil pada paper ini menunjukkan bahwa produk kWhmeter prabayar sudah efektif dengan persentase sebesar $71,43 \%$. Berdasarkan hasil survey yang dilakukan ada beberapa pendapat dari pelanggan yakni keuntungan dari penggunaan produk ini yaitu, mudah dalam pemantauan pemakaian energi listrik, mudah dalam pembelian Token, tidak perlu mengantri dalam pembayaran, mudah dalam pengaturan pemakaian energi listrik. Kemudian jika dilihat dari segi kesehatannya untuk pelanggan usia 45th keatas pada hasil survey tidak terdapat hal yang buruk, karena dapat dilihat pada pernyataan 2 dan 3 mengenai cara memasukkan nomor Token dan mengecek berapa sisa $\mathrm{kWh}$ pada monitor kWhmeter prabayar pelanggan merasa tidak ada kendala yang begitu berarti pada penglihatannya. Jadi pada paper ini produk kWhmeter prabayar sudah efektif dan membuat persepsi pelanggan usia pertengahan dan lansia PT.PLN (Persero) menjadi baik di wilayah Betngandang Sanur.

Berdasarkan hasil tersebut saran yang bisa diberikan oleh penulis untuk meningkatkan lagi tingkat dari efektifitas ialah dengan melakukan sosialisasi menggunakan berbagai media yang ada dan juga dengan melakukan penyuluhan di lingkungan atau banjar sehingga masyarakat dapat mengetahui cara pengoperasian kwh-prabayar secara baik dan benar.

\section{REFERENSI}

[1] Purwati. 2012. Efektivitas dan Dampak Dari Penggunaan KwhPrabayar Untuk Pelanggan PT. PLN (PERSERO) WS2JB Rayon Kenten Palembang. Jurnal Ekonomi Dan Informasi Akuntansi (JENIUS) : VoL. 2 No. 2 Mei 2012.

[2] Tjiptono, dkk. 2002. Strategi Pemasaran. Edisi-2, Yogyakarta. ANDI

[3] Hendarti, H., \& Gui, A. 2008. Korelasi antara Efektifitas Sistem Informasi Penjualan dengan Kinerja User

[4] Sugiyono.2011. Metode Penelitan Kuantitatuf, Kualitatif, dan R\&D. Bandung:Alfabeta

[5] Umar, dkk. 2003. Metode Penelitian untuk Skripsi dan Tesis Bisnis. PT. Raja Grafindo Persada. Jakarta

[6] Yusi. 2009. Metodologi penletian Ilmu Sosial Pendekatan kuantitatif.Citrabook Indonesia. Palembang

[7] Darlilis, R. 2008. Analisis kepuasan pelanggan terhadap kualitas pelayanan berkaitan dengan penanganan komplain studi kasus: PT. PLN (Persero) UPJ Pekalongan Kota

[8] Tung, L. L. U., \& Oktavia, H. 2009. KWh Meter dengan Sistem Prabayar. Proceedings, Komputer dan Sistem Intelejen (KOMMIT 2002)

[9] Susiono. 2010. Model Instalasi Listrik yang Dapat Mencegah Bahaya Kebakaran pada Bangunan. Majalah Teknik Elektro : Vol. 19 No.1 Januari - Juni 2010 
[Halaman ini sengaja dikosongkan] 